\title{
ВЛИЈАНИЕТО НА ЛЕКТИРИТЕ СО ИСТОРИСКА СОДРЖИНА ОД ПЕРИОДОТ НА ВЛАДЕЕЊЕТО НА ТУРЦИТЕ ОСМАНЛИИ И РЕЦЕПЦИЈАТА НА УЧЕНИЦИТЕ (КВАНТИТАТИВНА И КВАЛИТАТИВНА АНАЛИЗА)
}

\author{
Ајлин Карахасан \\ Универзитет „Св. Кирил и Методиј“, Скопје \\ ajlinkarahasan@gmail.com
}

Во овој труд ги претставувам резултатите од истражувањето на лектирите во наставните програми по македонски јазик и литература во средните училишта и нивното влијание врз знаењето на учениците за „културата на Друг̄ū̄е“, односно на припадници на заедниците во Република Северна Македонија. Главната цел на истражувањето е да се посочи улогата на наставната интерпретација на лектирите во развивањето емпатија, разбирање на другите, различните од себе, во поттикнувањето дијалог и интеракција меѓу учениците од различна националност. Студијата, истовремено, зазема критички став кон сопствената и кон туѓата култура и традиција, потенцирајќи ја важноста на преиспитувањето и на личната трансформација, а со цел препознавање на идентитетските претстави, на етничките и на верските стереотипи и предрасуди кај себе и кај другите, што би обезбедило механизми за нивното надминување во училишната практика. Дополнително, студијата настојува да ги согледа заедничките, универзалните, општочовечките хумани вредности што придонесуваат за надминувањето на разликите и за препознавање на вредностите што се содржани во хуманистичката димензија на книжевните дела што се предмет на анализа. Во овој контекст, преку анализа на стереотипите и на индивидуалните ситуации, се настојува да се укаже на можностите за оформувањето на карактерот на учениците во духот на културата што се залага за меѓуетничка толерантност.

Клучни зборови: историја, лектири, педагогија, стереотипи, предрасуди 


\section{THE INFLUENCE OF THE READINGS WITH HISTORICAL CONTENT FROM THE PERIOD OF TURKISH-OTTOMAN RULE AND THE RECEPTION OF THE STUDENTS (QUANTITATIVE AND QUALITATIVE ANALYSIS)}

Aylin Karahasan

Ss. Cyril and Methodius University, Skopje

ajlinkarahasan@gmail.com

In this paper, I present the research results from the required readings in the curricula of Macedonian Language and Literature in high schools as well as their impact on the awareness of students about the "culture of Others" as members of the communities in the Republic of North Macedonia. The main goal of the research is, through literary analysis of textbooks, to develop empathy, understanding of others, of those different from themselves, to develop dialogue, communication, and interaction between students of different nationalities. The study, at the same time, is an analysis in which a critical attitude towards one's own and other people's culture and tradition is taken. There is a re-examination and personal transformation in order to recognize the identity representations, ethnic and religious stereotypes, and prejudices among ourselves and others, which would serve as a way to build mechanisms for their overcoming when implemented in schools. On the other hand, this study endeavors to identify the common, comprehensive, universal human values that contribute to overcoming differences with the goal of finding those universal human values in the literary works that are the subject of analysis. In this context, through the presentation and analysis of stereotypes and individual situations, efforts are made to point out the possibilities for shaping the character of children and students in the spirit of the culture of interethnic tolerance.

Keywords: history, reading, pedagogy, stereotypes, prejudices 


\section{1 Интерпретација на историските романи во наставните програми по македонски јазик и литература}

\section{1 Мултикултурни релации}

Италијанскиот поет Франческо Петрарка вели:

Книгите ми одговараат на сите прашања што им ги поставувам. Едни ми кажуваат за некогашните настани, а други ми ги откриваат тајните на природата. Едни ме учат како да живеам, а други како да умрам. Едни со својата живост ги изгонуваат моите грижи и ми ја веселат душата, а други ми го крепат духот и ме поучуваат како да ги ограничам своите желби и да верувам во самиот себе (Fera, Martelli 1998: 251).

Но, дали овие зборови на Петрарка, изречени пред седумстотини години, важат за нашето време, кога покрај книгата силно влијание имаат и современите средства за комуникација, особено интернетот? Истражувањата се насочени кон книгата, која има свои одлики што не се дел од ниту едно аудиовизуелно средство.

Училиштето својата задача за насочување на децата кон книгата ја реализира врз основа на наставната интерпретација на лектирите, предвидени со наставните планови и програми за различни возрасти. За да се даде правилна насока во интелектуалниот развој на ученикот, се формираат и определени убедувања, однесувања, ставови, вредности, при што значајна улога играат содржината, начинот на изведување на наставата и организацијата на училишниот живот (Штајнбергер, Кузмановиќ 1985: 80). Со други зборови, лектирите се мошне значајни во развојот на карактерот на ученикот, бидејќи честопати се добиваат многу статични и стереотипни слики за Друг̄име - за нивниот идентитет, вредносниот систем, културата на живеењето, обичаите, однесувањата. Оттаму е и важноста на начините на кои се реализира наставната интерпретација на лектирите и улогата на наставниците во надминувањето на негативните претстави во свеста на учениците за другите култури. Наместо појавата на љубов, разбирање и толеранција кон разликите и яруг̄ости $а$ во културолошка смисла, може да се појави нетолеранција, па и конфликти меѓу децата, особено оние што се од различна етничка или религиозна припадност. Во однос на критериумите за избор на книжевните дела (лектирите), како соодветни за детската рецепција, антрополошкиот и психолошкиот пристап секогаш ја имаат предвид возраста. Оттаму, се тврди дека литературата за деца треба да го содржи критериумот едноставност. Како што вели и Тодорова (2012: 20), книгите треба да им ги отворат видиците на учениците кон другите култури и начини на живот, помагајќ́ им на тој начин да ги надминат стравовите што потекнуваат од непознавањето.

Актуелната состојба покажува дека во наставната програма во нашата држава се застапени лектири со историска тематика како што се: Калеш Анг̈a,

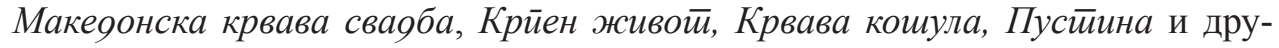


ги дела во кои се претставени страдањата на македонското население под ропство. Притоа, прикажаната слика е супериорна по однос на историските или емпириските сознанија од секојдневното искуство во кое разнообразните аспекти даваат многу пошарена слика, наместо поедноставената, сведена на рамката во која има само две спротивставени страни: првите се поробувачите, а другите се поробените. ${ }^{1}$ Отсуството на толкувања во мултиетничкото општество секогаш ги трпи последиците од стереотипно изградените слики, кои на учениците, преку лектирата, која не е доволно широко и во историскиот контекст анализирана, им ја пренесуваат идејата на авторите. Токму во овој момент улогата и функцијата на наставникот е многу значајна за подигнување на свеста за разликите, за поттикнување на емпатија кон припадниците на различните култури, а тоа ѝ дава квалитет на наставната интерпретација, ги отстранува ограничените перспективи и влијае врз разбирањето на историските настани претставени во книгите. Во исто време, тоа има влијание и врз актуелниот однос кон припадниците на мултикултурните заедници. Како што укажува и познатиот педагог Адолф Дистервег: „Изворот на интересот, возбудувањето и љубопитноста е во односот со самиот учител, со неговото непосредно влијание врз учениците“ (Rotenberg 1997: 4). Оттаму, особено е значајно како наставникот ке ги доближи настаните прикажани во книжевните дела до своите ученици, вложувајќи особено во методичкото обликување на наставната интерпретација, затоа што преку книгите со историска содржина учениците се запознаваат со минатото на својот народ и со етапите на конструкција на неговиот идентитет, воопшто. Она што ќе се вложи, секогаш се враќа како долгорочен ефект. Во спротивно, доколку книжевните тематизации и прикази на насилството во лектирите не бидат контекстуално интерпретирани, може да бидат стимулирачко средство за агресивното однесување на учениците кон Друг̄uйе во реалниот живот. Затоа во наставните програми треба да бидат застапени лектири што ќе ги задоволуваат емоционалните, интелектуалните и моралните потреби на учениците. Вообичаено, посочувањето на проблемите се поима како критика што не води секогаш до нивно решавање. Последиците се најчесто поврзани со чувствата на подреденост, со арогантниот начин на справување, со висока доза на обезвреднување на проблемите во комуникацијата меѓу „Јас“ и „Другиот“. Всушност, се работи за навика на размислување и на однесување, за наметнат репер или за таканаречен вредносен код, кој, очигледно, во процесот на зреење влијае на оддалечување, а не на зближување преку меѓусебно запознавање и толкување на специфичните културни, историски или општествени контексти и нивна споредба со современоста. Единствена можност и излез е неопходноста од системско-образовно рестартирање на процесите, што би придонеле за нормализирање и за примена на вредностите поврзани со разбирањето, со проникнувањето меѓу културите, со запознавањето на разликите, но и на сличностите што се клучни фактори во подигање на стандардите и релевантноста на образованието, како темел на секоја здрава заедница.

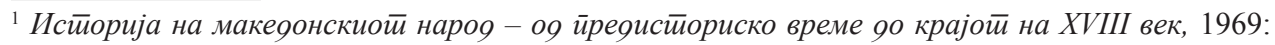
229-255. 
Основна цел на ова истражување е да се анализира степенот на ефективност и на ефикасност на делата со историска содржина, кои се дел од задолжителната лектира во наставата по македонски јазик и литература, а кои имаат влијание врз свеста кај учениците и врз информираноста во еден поширок спектар од разбирања и читања на содржините.

\section{2 Интерпретација низ практиката во истражувањето}

Целна група врз која е извршено истражувањето се ученици од средните училишта на територијата на град Скопје. Тоа се:

1. СУГС „Јосип Броз Тито“- Скопје - 194 испитаници;

2. СУГС „Раде Јовчевски - Корчагин“- Скопје 177 испитаници;

3. СУГС „Орце Николов“ - Скопје - 191 испитаник;

4. СУГС „Никола Карев““ - Скопје - 149 испитаници.

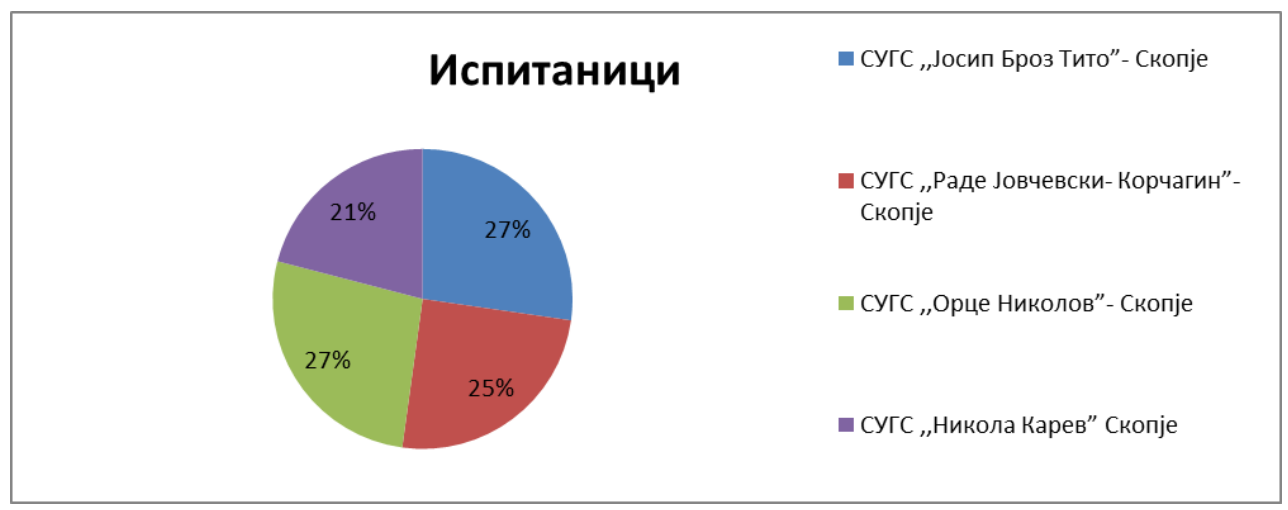

Графикон 1.

2.1 Вкупна бројка на испитаници е 711 ученици, од кои 265 се изјасниле дека се од машки пол, а 446 ученици од женски пол.

Табела 1.

\begin{tabular}{|c|c|c|}
\hline Пол & ИСПИтАНИци & \% \\
\hline Машки пол & 265 & $37,2 \%$ \\
\hline Женски пол & 446 & $62,8 \%$ \\
\hline Не одговориле & нема такви & $0 \%$ \\
\hline Вкупно & 711 & $100 \%$ \\
\hline
\end{tabular}


2.2 Возраста на испитаниците е во опсег од 14 до 18 години, односно:

1. 5 испитаници на 14-годишна возраст;

2. 197 испитаници на 15-годишна возраст;

3. 283 испитаници на 16-годишна возраст;

4. 198 испитаници на 17-годишна возраст;

5. 28 испитаници на 18-годишна возраст.

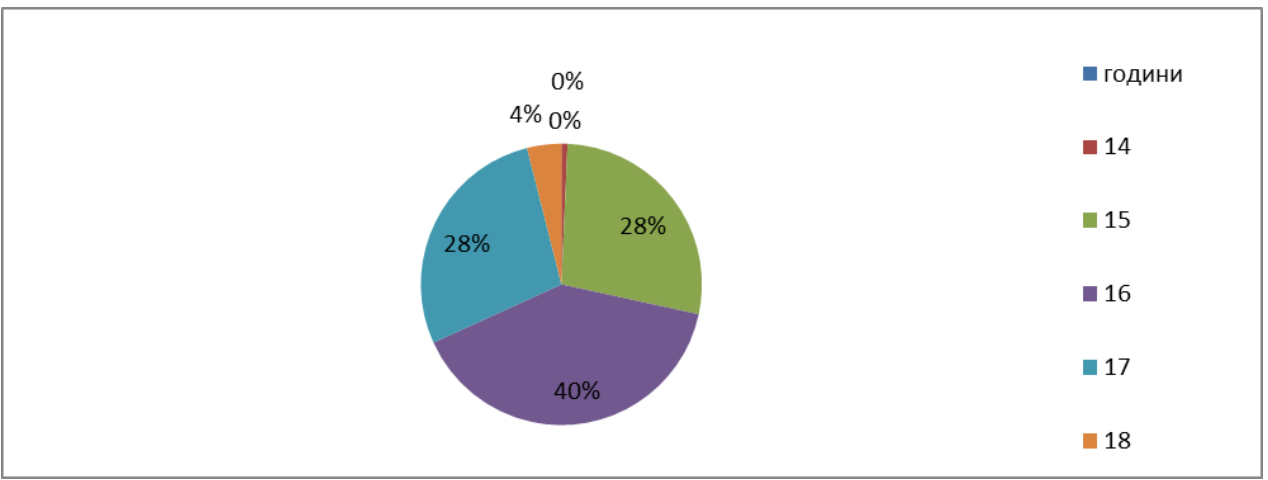

Графикон 2.

2.3 Испитаниците што беа вклучени се од четиригодишно средно гимназиско образование. И тоа:

1. прва година средно образование - 175 испитаници;

2. втора година средно образование - 314 испитаници;

3. трета година средно образование - 203 испитаници;

4. четврта година средно образование - 19 испитаници;

5. не одговориле за година на образование: /

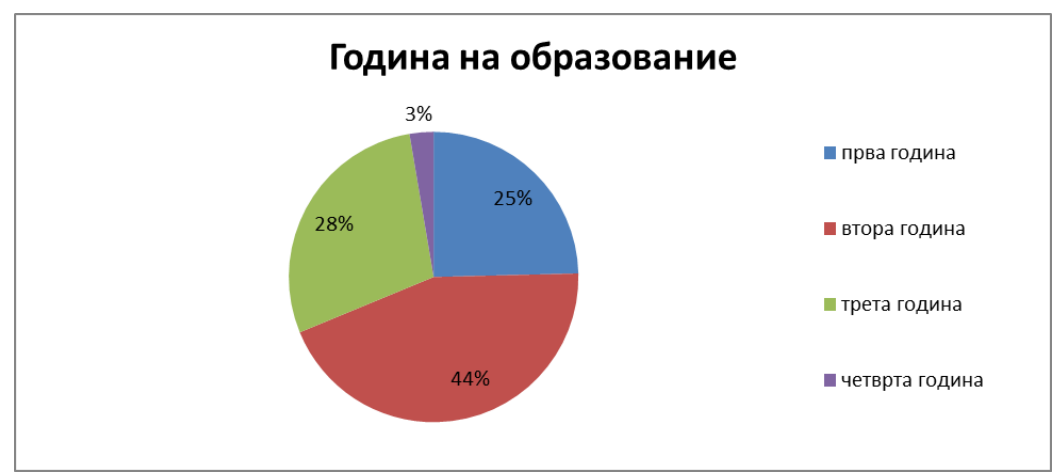

Графикон 3.

За потребите на ова истражување беше изготвен полуструктуриран нацрт-прашалник, со квалитативен и квантитативен пристап, како инструмент со кој ќе се утврдува влијанието на лектирите со историска содржина, како и потребата од подигнување на свеста на наставниците и учениците во насока на разбирање на културите и контекстите во минатото низ современа перс- 
пектива. Подготвителната фаза на истражувањето содржеше активности што обезбедија солидна основа за соодветно прибирање на податоците неопходни за анализа, како што се консултации и телефонска комуникација на дневна основа со директорите на училиштата и со предметните професори по македонски јазик и литература, со цел обезбедување на максимум информации. По финалните корекции и приспособувањата на прашалникот, кои се утврдија во координација со предметните професори, тој е составен од вкупно тринаесет прашања, од кои: со девет се добива дескриптивен одговор, четири се од отворен тип, односно избор на повеќе од еден од понудените одговори. Времето на пополнување на прашалникот е максимум 15 минути. Дистрибуцијата на анкетниот прашалник поради пандемијата се одвиваше онлајн и беше подготвен преку програмата Microsoft forms. Линкот од прашалникот беше доставен до координаторите на училиштата и до предметните професори по македонски јазики литература. Анкетниот прашалник беше пополнуван за време на часот од страна на учениците и препратен преку истата програма. Рокот на пополнување на анкетниот прашалник беше 29 јануари 2021.

\section{3 Конкретни резултати од истражувањето}

Луѓето честопати му дозволуваат на минатото да ги ограничува можностите на сегашноста и иднината, затоа што неуспехот да се справат со стереотипите и со предрасудите ги принудува да мислат дека никогаш нема да можат ефикасно да го разрешат. Во ваков случај спротивставените страни мислат дека, затоа што не можеле да ги решат меѓусебните проблеми во минатото или, пак, нивниот однос во минатото се сведувал на битката за доминација над другата страна, залудно е да се очекува дека би можеле да се однесуваат поинаку. Како што тврди Викс, познатиот политички филозоф:

Минатото нуди искуствена рамка за сегашноста и за иднината, но не смее да биде подлога во која сегашноста и иднината ќе бидат неповратно вкоренети. Сегашноста ги поставува сеќавањата од минатото на нова подлога и ги обработува со помодерни алатки, секогаш свесна дека иднината ќе го ожнее она што сегашноста го посеала (Weeks 1994: 61).

Поделбата на луѓето на групи врз основа на некој критериум ги поттикнува припадниците на групата да се дефинираат себеси како „ние“, а другите како „тие“ и меѓусебно да се споредуваат и да донесуваат судови едни за други. Со други зборови, директните судири меѓу групите околу вредностите уште повеќе го засилуваат процесот на стереотипизирање. Луѓето честопати се сеќаваат само на негативното однесување на Друг̄uой во минатото, одбивајќ́ да ги прифатат позитивните потенцијали дури и кога другата страна се однесува поинаку во сегашноста. Всушност, ваквата појава е типичен пример за тоа како минатото се користи за осуетување на можноста за подобрување на меѓусебните односи (Петроска-Бешка 1995: 28-31). Во интервјуто со д-р Камелија Симеонова, семеен и системски советник, специјализант по детска и адолесцентна психијатрија, дојдовме до заклучокот дека најпримарна филогенетска емоција е стравот, така што уште од почетокот на човековиот 
живот луѓето имаат потреба да се врзуваат и да имаат страв од дисконекција. Влијанието на литературата со историска содржина врз децата таа го смета како трауматско искуство, бидејќи преку овие дела на децата им сервираат приказни за настани поврзани со убивање мажи и со силување жени. Детето го сфаќа тоа како дисконекција од социјалната врска, поточно од единствената и најсилна емоција. Така, на децата тоа што им се врежува е дека Турците Османлии се злосторници, силувачи на најсаканите и тоа претставува најтрауматско искуство. Наставникот, доколку ги пласира сите овие информации со напомена дека станува збор за војна и дека тоа го прави секој народ за време на војна, со други зборови, дека за време на војна убиството е начин на одбрана и на функционирање, потенцирајќи го фактот дека целта не била изживување, во тој случај детето/ученикот би имал сосема друга слика за настаните. Професорот не треба да дава детали за настаните, туку да се фокусира врз приказната: со децата се разговара низ приказна и колку помалку трауматски информации се споделуваат со нив толку помалку трауматски ја доживуваат ситуацијата. Поточно, ако на детето му се објасни дека Османлиите биле најмоќни во тоа време и дека сето тоа се случувало за време на војна, децата би имале дури и позитивно размислување за нив. Од друга страна, Симеонова додава дека не може да се одбегне моментот на поробувањето, поточно, кога веќе немало војна, во тој случај децата доживуваат посттрауматско стресно раствојство. Поробувањето значи „губење идентитет и припадност“, така што првична е акутната стресна загуба (акутно стресно растројство, по кое следува посттрауматско). Поробувањето не спаѓа во нормални животни циклуси, тоа е состојба на криза. Децата на кризата реагираат со регресија, со себеповлекување, со страв, со агресија и со несоодветно однесување. Во овој момент во однесувањето на детето доминираат бесот, дисхармонијата, цикличното расположение, со бројни флеш-бекови, како, на пример, мирис на крв од војната, сцени на жртви, сцени на измачување некого и сл.

За да се неутрализира негативното влијание на минатото врз сегашноста и иднината, неопходно е, освен нарацијата за негативните искуства и поделеноста меѓу оние што се господари, оние што се претставени како насилници и потчинетите кои страдаат во тортури или во сиромаштија, да се дејствува во насока и на потсетување на настаните кога и двете страни уживаат во стабилно партнерство. Вообичаено е на негативните настани од минатото да им се даде негативен тон на целокупното минато. Потсетувањето на позитивни настани од минатото им овозможува на страните конструктивно да му пристапат на проблемот (ibid., 28-31). Токму затоа намерата на ова истражување е да се анализира влијанието на лектирите со историска содржина во кои Турците Османлии се ликови што се негативно претставени, врз учениците и врз современите слики за Турците. Наследените или традиционалните релации, обележани со дистанца, се дел од преиспитувањата на кои упатува ова истражување, а низ кои се тестира моќта на комуникација меѓу учесниците во наставниот процес. Од друга страна, развојот на сензитивноста кон Другиоой е услов за надминување на чувството на маргинализираност, навреденост и негово обезвреднување. Резултатите од овој научноистражувачки труд го преиспитуваат пристапот кон комуникацијата во наставниот процес за да го од- 
дели она што е составен дел од навиките на размислување и однесување како наметнат репер за вреднување и обезвреднување. Истовремено, резултатите од ова истражување треба да влијаат врз отворањето платформи и можности за системско-образовно рестартирање, што би придонело за нормализирање и за примена на толкувањето, на дијалогот, на естетските вредности, на културните разлики и односи низ кои се развиваат способностите на ученикот да мисли и да решава проблеми, да размислува критички и да застапува ставови соодветни на современата научна мисла во компаративните и во студиите за културата. Во стратегијата на преиспитувања на културите и нивните односи преку романите од наставните програми и историјата, значајно место добиваат моралните вредности, како клучни фактори во подигање на стандардите и на релевантноста на образованието, темелот на секоја здрава заедница.

\section{4 Анализа на резултатите}

Анкетниот прашалник имаше цел да открие како турската култура претставена во книгите со историска содржина влијае врз учениците од современата епоха, со оглед на застапеноста на таквите книги, т.е. лектири во наставните програми во Република Северна Македонија. Во овој контекст се анализираа можностите за градење слика за една култура под влијание на она што е прикажано во книгите. Истовремено, ваквото истражување ги анализира и проблемите тесно поврзани со предрасудите, со стереотипните слики за Друг̇ūe, потоа прашањата поврзани со културните идентитети, со вредносните системи, со културата на живеењето и обичаите, со однесувањата во врска со вреднувањето различни појави. Аналитички се проследени одговорите на учениците од средно образование на поставените прашања во анкетникот.

1. На прашањето: „Во колкава мера претставувањето на Турците Османли во делата од македонската литература што си ги прочитал/а влијае врз твојата перцепција за нив“, испитаниците одговориле со повеќе можни одговори:

a) Има големо влијание - 440 испитаници;

б) Има делумно влијание - 169 испитаници;

в) Нема никакво влијание - 102 испитаници.

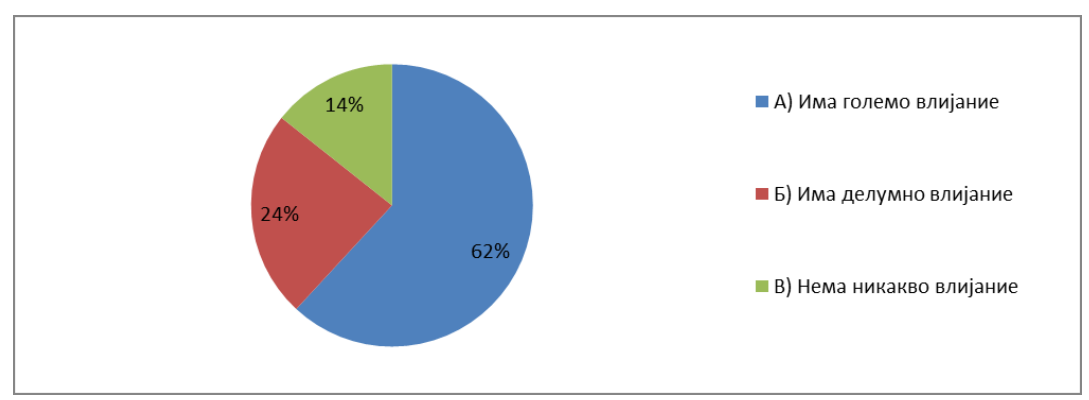

Графикон 4. 
Целта на првото прашање беше да се утврди во колкава мера е актуелна темата на претставување на Турците Османлии во делата од македонската литература, а кои извршиле влијание врз перцепцијата на читателите. Поголемиот дел од испитаниците (62 \%) одговориле дека литературата на подиректен начин влијае врз нивната перцепција за Турците Османлии, иако тие немале непосреден допир со настаните. Искуствата раскажани во народната литература, фолклорните обичаи и погледите ги сметаат за пореални во споредба со историјата, која главно е базирана на факти. Тие ги доживуваат Турците Османлии како напаѓачи, освојувачи, кои се причина за тешкиот живот на населението во земјите во кои владееле. Од друга страна, 24 \% од испитаниците одговориле дека тоа делумно влијае врз нивната перцепција, поради тоа што дел од нив се изјасниле дека читаат многу повеќе на интернет, гледаат филмови и тоа им придонесува да имаат барем малку поразлична слика за нив. 14 \% од испитаниците одговориле дека книжевните дела не играат никаква улога во нивната перцепција за Турците Османлии, сметајќи го тоа како минато, па литературата може да даде само некаква претстава за тогашниот живот и случувања, без да влијае врз нивното убедување или врз изведувањето генерализирана слика за цел народ низ историјата и во современоста.

Во дел од одговорите на учениците се вели:

Дефиниииивно мног̄y, gо йрея скоро време јас самайа сметиав яека и Туриииее како нароя се лоши луг̈е со многу заостианайи религиозни размислувања, а денес фознавам дека и не е йака.

Во голема мерка. Лииеерайурайа овозможува ирриказ на она шимо секој оя нас

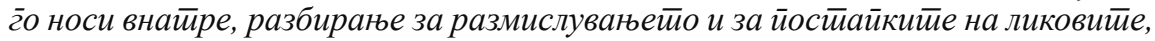

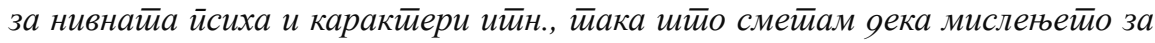
Османлиите ми е во голема мера формирано йокму оя яелайа шимо сум гии

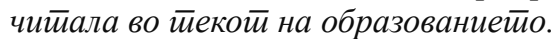

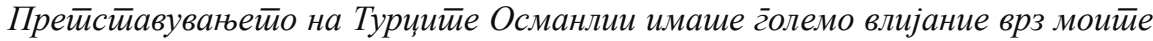
размислувања за нив. Секако, йоа бете иеериоя ког̄а еяинсиивени информации

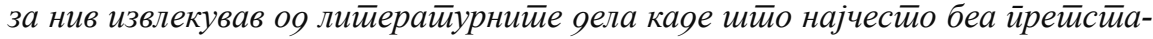
вени како негайивни ликови. Сейак, моейо мислење за нив е йроменейо йо

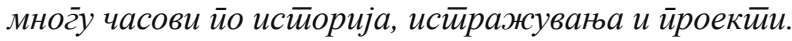

2. Дали е поголемо влијанието на другите извори на информации за Турците Османлии (историски дела, учебници) во однос на книжевните дела како извори на информации за нив?

а) Да, влијанието на другите извори е поголемо од книжевните дела - 550 испитаници;

б) Не, влијанието на другите извори не е поголемо од книжевните дела -100 испитаници;

в) Влијанието е подеднакво - 61 испитаник. 


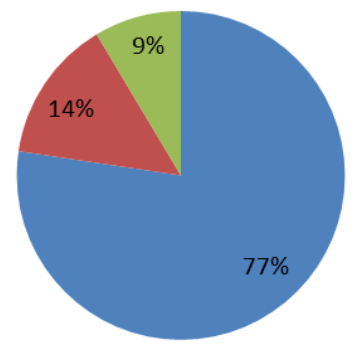

А) Да, влијанието на другите извори е поголемо од книжевните дела.

Б) Не, влијанието на другите извори не е поголемо од книжевните дела.

в) Влијанието е подеднакво.

\section{Графикон 5.}

Целта на второто прашање беше да се утврди разликата меѓу влијанието од другите извори на информации за Турците Османлии (историски дела, учебници) и она на книжевните дела. Поголемиот дел на испитаниците (77 \%) одговориле дека преку учебниците се добиваат попрецизни и стручни информации во споредба со книжевните дела, каде што повеќе е акцентиран начинот на кој народот ја доживувал и ја преживувал окупацијата, со тоа што ништо не го спречувало авторот да ја измени приказната и да ја направи ситуацијата да изгледала полоша или подобра од реалната. 14 \% од испитаниците сметаат дека влијанието на книжевните дела е поголемо, бидејќи ја претставува реалната слика за теророт што се случувал врз македонското население, со тоа што се даваат повеќе детали за тој историски период, кој им овозможува на читателите да се соживуваат подобро со случувањата. Најмал дел од испитаниците (9\%) сметаат дека е влијанието подеднакво, додавајќи дека сите извори на информации имаат своја тежина, со тоа што луѓето не треба да се потпираат на само еден извор за да донесат заклучок за одреден период или настан.

Дел од одговорите на учениците:

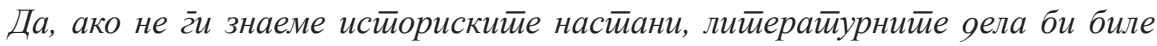

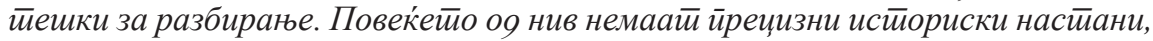
иуку секојяневни.

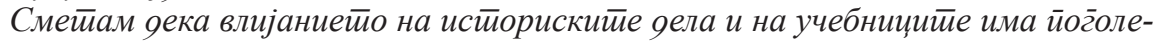
мо влијание врз нашетио размислување, бияејќи ние ја сметиаме лииерайура

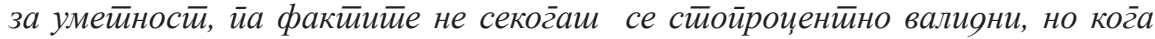

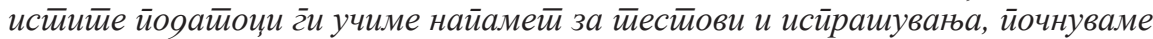
нависиина яа веруваме во йоа.

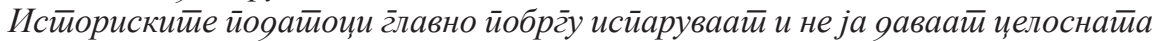

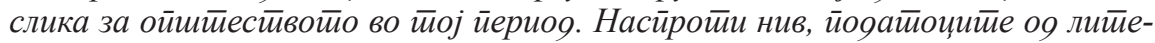

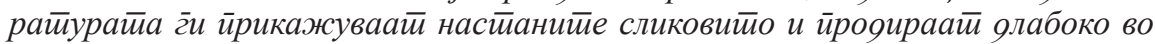

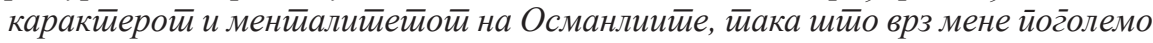

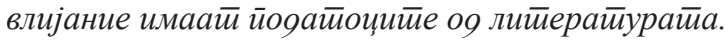

3. Кое е твоето размислување за начинот на кој се прикажани Турците Османлии во делата од македонската литература што си ги прочитал? 
а) Не се реално прикажани и треба да се зборува повеќе за тој период - 9 испитаници;

б) Се реално поточно прикажани во негативна слика - 616 испитаници;

в) Немам никаква претстава за нив -8 испитаници.

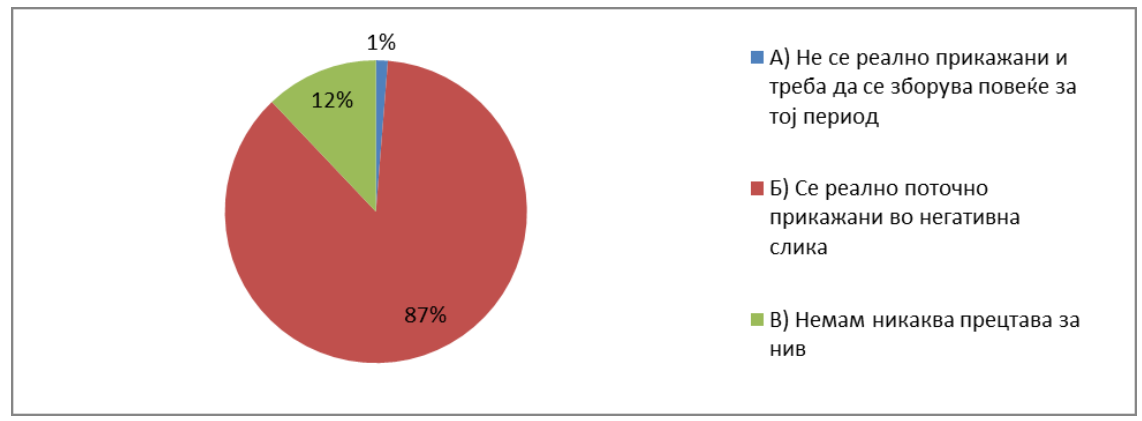

Графикон 6.

Со третото прашање се отсликува размислувањето на учениците за начинот на кој се прикажани Турците Османлии во книжевните дела. Голем процент од одговорите (87 \% од испитаниците) се изјасниле дека Турците Османлии и тие мрачни години се прикажани во реално светло: тие се опишани како мошне сурови, жедни за власт, подготвени на секаков начин да се здобијат со посакуваната цел на сметка на уништувањето голем број животи, со поништување или одземање на правата на луѓето. 1 \% од испитаниците тврдат дека тоа било време на војна, па авторите со помош на тие дела ја опишале ситуацијата од своја перспектива, но тоа не го менува фактот дека е тоа прикажано субјективно. 12 \% од учесниците се изјасниле дека немаат конкретно мислење за начинот на кој се прикажани Турците Османлии во македонската литература.

Дел од одговорите на учениците:

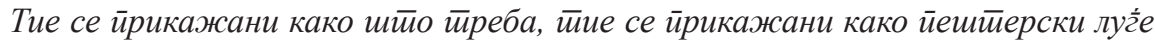

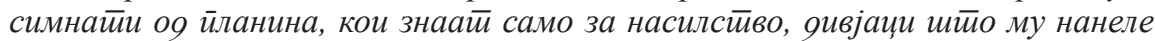

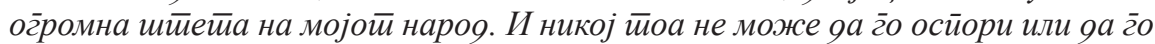
иромени.

Многуу сурови, грруби, исиолнейи самите со себе. Газеле сѐ ӣрея себе за gа

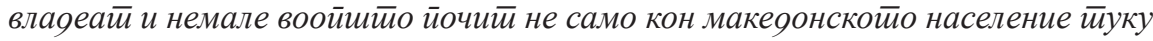

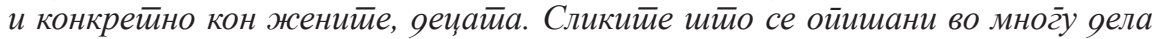

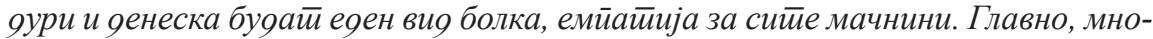
гу лош нароя.

Јас мислам фека се иррикажани йака како шито биле, сигуурно имало и йолоши

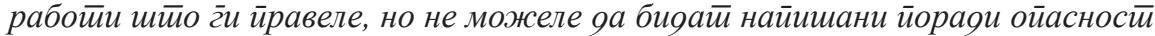
за живойийе на авйорийе.

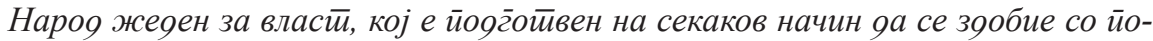

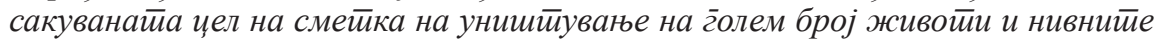
ирава и слобояи.

4.Дали постојат стереотипи во начинот на кој се прикажуваат Турците Османлии во делата на македонските писатели? 
а) Да, постојат - 533 испитаници;

б) Не, не постојат - 78 испитаници;

в) Можеби - 100 испитаника.

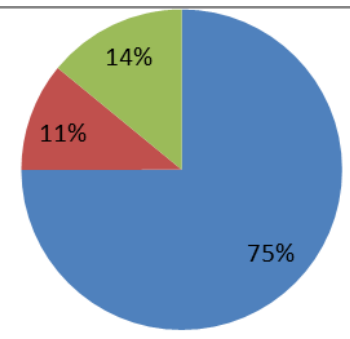

п) Да, постојат.

Б) Не, не постојат.

в) Можеби

\section{Графикон 7.}

Според Петроска-Бешка, стереотипите, пред сѐ, се фактори што произлегуваат од конфликтните ситуации, а не фактори што, во основа, ги предизвикуваат конфликтите, иако можат да придонесат за нивно влошување (1995: 29). Во горенаведеното прашање целта беше да се утврди дали според учениците воопшто има стереотипи во начинот на кој се прикажуваат Турците Османлии во делата на македонските писатели. Голем број од испитаниците (75 \%) одговориле дека постојат стереотипи за Турците Османлии, почнувајќи од нивниот изглед до начинот на кој се однесувале кон македонското население. Од друга страна, 11 \% од испитаниците сметаат дека во делата се покажува и човечката страна, како и општественото уредување на османлиската власт, која настојувала да биде надредена во рамките на администрирањето на односите со локалното население каде што владееле. Според одговорите на оваа група испитаници, во делата се прави дистинкција дека насилството често е правено од страна на локалните турски моќници, кои не ги почитувале законите на Отоманската Империја или од страна на локалните муслимански групи, одметнати од законот, кои дејствувале со башибозукот, како вооружени криминалци и пљачкаши. 14 \% од испитаниците немаат конкретно мислење за ова прашање.

Дел од одговорите на учениците:

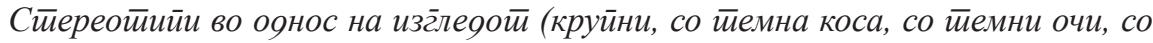
големи мусииаки, ирвен фес). Луг̈е без иочиий кон никог̄о, освен кон сойсииве-

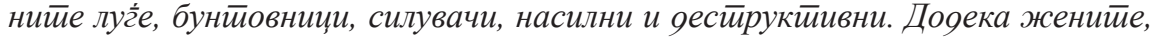
йак, се вообичаено йокорни, иокриени яо колена, но физички многуу убави.

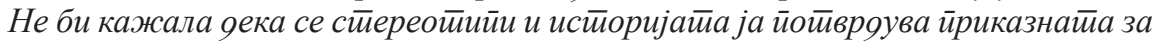
Турииие Османлии, кои гоо иоонижуваай и йокоруваай Макеяонецой.

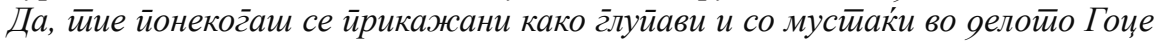
Делчев, ииој ирравел муабей со нив, а ииие не го ирреиоознале.

Повеќето се сиеереойийи йоврзани со муслиманстивойо. 
5. Кој лик од Турците Османлии во делата од македонската литература ти оставил најсилен впечаток и зошто?

а) Осман бег од Макеоонска крвава сваяба - 423 испитаници;

б) Калеш Анѓa - 188 испитаници;

в) Султан Сулејман - 45 испитаници;

г) Раим чауш во делото Толе йаша - 5 испитаници;

д) Насредин оџа од приказните на Итар Пејо - 14 испитаници:

ѓ) Ниту еден лик конкретно- 36 испитаници.

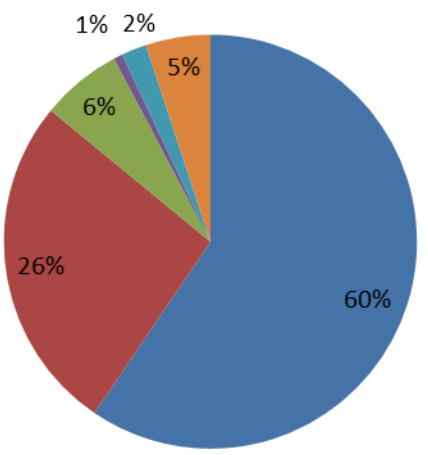

$$
\begin{aligned}
& \text { А) Осман бег од македонска } \\
& \text { крвава свадба } \\
& \text { Б) Калеш Анѓa } \\
& \text { в) Султан Сулејман } \\
& \text { г) Раим чауш во делото Толе } \\
& \text { паша } \\
& \text { Д) Насрадин оџа од приказните } \\
& \text { на Итар Пејо } \\
& \text { ѓ) Ниту еден лик конкретно }
\end{aligned}
$$

\section{Графикон 8.}

Горенаведеното прашање е поставено со цел да се добие одредена слика за специфичноста на определени ликови и за пристапот на авторите што го претставуваат ликот на Турците Османлии надвор од стереотипните идентификации. 60 \% од испитаниците го издвоија ликот Осман бег од Макеgонска крвава свабба, сметајќи го за крајно негативен лик, но истовремено, како одлично изграден лик, преку кој успешно се покажуваат сите карактеристики на еден османлиски бег од тој историски период. Додека 26 \% испитаниците, пак, го издвојуваат ликот на Калеш Анѓа поради фактот дека одбива да се потурчи. 6 \% од испитаниците го одвоиле ликот Султан Сулејман, бидејќи е прикажан како многу успешен владетел, кој имал големи достигнувања и за кого се говори и денес. Мал број од испитаниците (2 \%) го истакнуваат ликот Насрадин Оџа како лик што успевал да надмудри и, во исто време, да го покаже отпорот на македонското население против турското угнетување. $1 \%$ од учениците се под влијание на претставата за ликот Раим Чауш од делото Толе Паша поради фактот што „тој ги ловел“ комитите со огромна војска. 5 \% од испитаниците одговориле дека нема конкретен лик што им оставил впечаток. Традиционалните вредносни судови за местото и за улогата на половите застапени во литературата влијаат на подлабоко ниво со тоа што значителен број од испитаниците (97 \%) одговориле дека машките ликови во лектирите каде што се застапени Турците Османлии значително се побројни поради фактот дека, секогаш кога во литературата се претставувал настан поврзан со Османлиите, тој настан бил во врска со борбата за слобода. Жената, пак, 
играла поголема улога во домаќинството, за разлика од мажот, кој учествувал во ваквите судири.

Дел од одговорите на учениците:

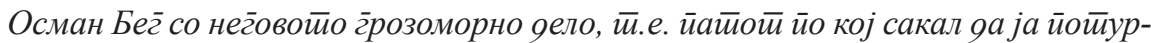

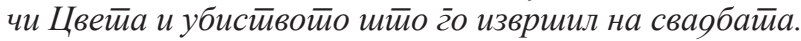

Ликой Осман, йо кој е именувано Османлискойо Царсииво, за нег̄о најг̄олем

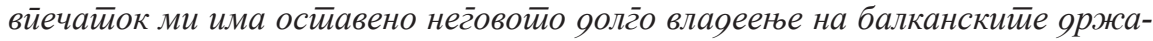

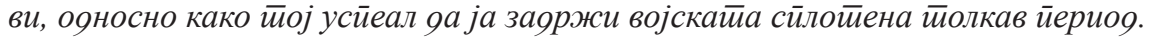

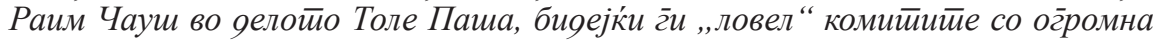
војска.

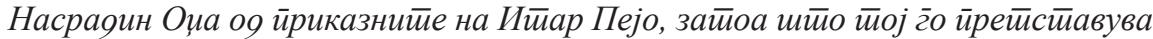

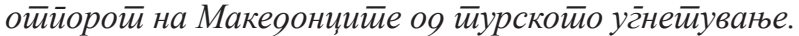

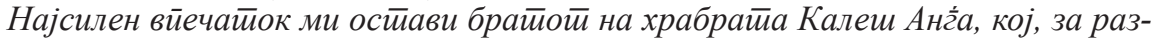

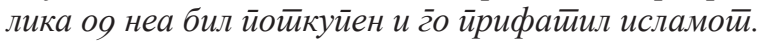

6. Чие мислење за целината на делото, како и за ликовите на Турците Османлии, во текот на интерпретацијата на делото има најголемо влијание врз твоето размислување за нив?

а) Мислењето на професорот - 293 испитаници;

б) Мислењето на народот - 56 испитаници;

в) Мислењето на авторот/делото - 262 испитаници;

г) Моето мислење јас сам/а го градам - 81 испитаник;

д) Не одговориле - 19 испитаници.

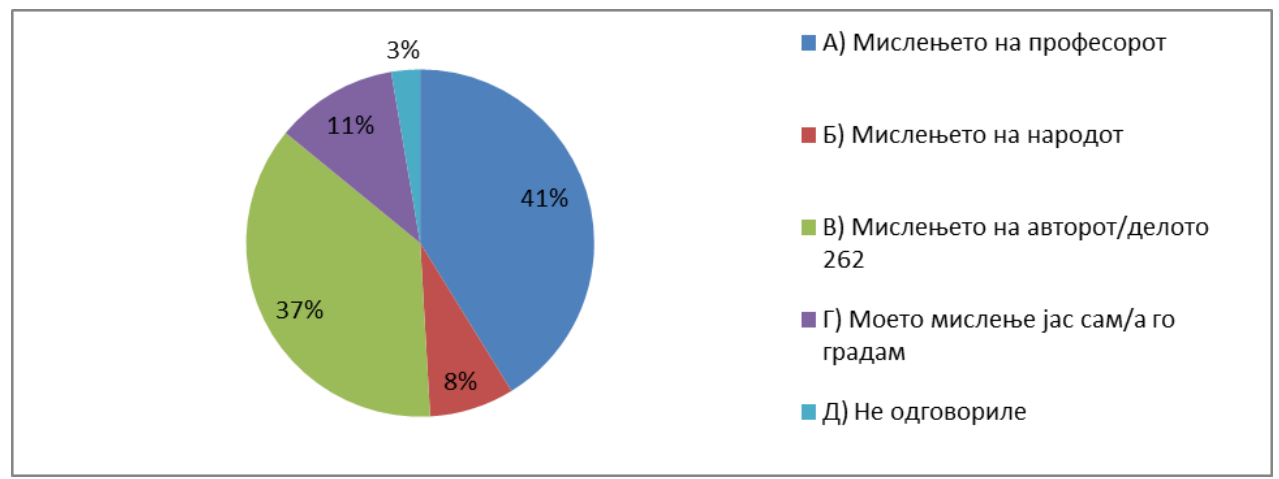

\section{Графикон 9.}

Горенаведеното прашање е поставено со цел да се утврдат наставните процеси на интеракција и начинот на кој во наставата се интерпретираат делата во кои има ликови на Турците Османлии. Во таа смисла, се говори за тоа колку наставниците успеале преку наставната интерпретација да влијаат врз учениците при градењето слика за ликовите на Турците Османлии. Голем дел од испитаниците (41 \%) одговориле дека најчесто професорот е највлијателен, тој дава вовед за делото пред да биде прочитано и на тој начин ја ограничува нивната субјективната интерпретација на делото. Од друга страна, 37 \% од испитаниците одговориле дека мислењето на авторите е мошне влијателно 
за нивната перцепција за Турците Османлии, цитирајќи ја реченицата на Војдан Чернодрински: „Јас не найишав нишӣо, јас само ја йрейишав крвавайа

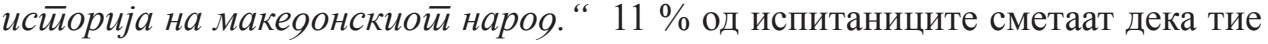
лично го оформуваат сопственото мислење при читање на делото, но не го негираат фактот дека можеби потсвесно има влијание интерпретацијата што ја нуди авторот преку сижето и ликовите. Осум проценти од испитаниците сметаат дека мислењето што произлегува од прочитаната лектира може да се сумира во сознание и слика за тоа дека грабнувањето на младите македонски деца со сила ги наведувало нивните родители да им отсечат прст или да им направат крст на челото, а реченицата „умрев, но Турчинка не станав“, е највлијателна по однос на искажаниот отпор на жената. 3 \% од испитаниците не одговориле на прашањето. Потпрашањето поставено во врска со влијанието на интерпретацијата на делата врз промената на претставата за Турците Османлии кои ги имале дотогаш има за цел да утврди дали постојат дела што ја менуваат стереотипната слика за Турците Османлии и на кој начин тоа е направено низ нарацијата. 89 \% од испитаниците сметаат дека нивната слика за Турците Османлии по прочитаните дела не се сменила; 5 \% од нив одговориле дека мислењето им е сменето, но во негативна смисла, а 4 \% од испитаниците одговориле дека нивното мислење делумно се сменило поради фактот што имаат пријатели Турци и дека тоа било период во минатото. 2 \% од испитаниците не одговориле на ова прашање.

Дел од одговорите на учениците:

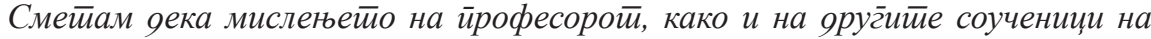

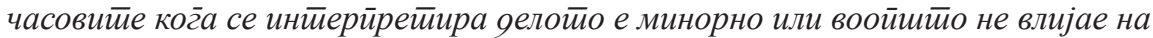

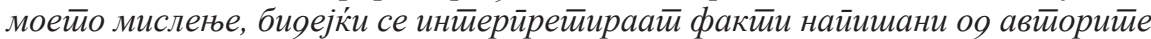
и свеяоиите на овие случки, а не се формира мислење оя сойсиввени убеяувања. Врз мојайа иеерцейицја за нив еяинсиивено може gа влијае gелойо или воойшйо йояайоциие оя кој било извор яо кој сум оошла.

Најбийно ми е мислењетио на Макеяониите шимо живееле во Ойоманско-

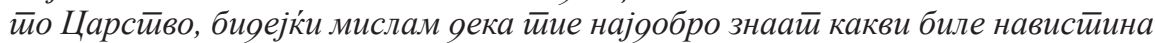
Турииие Османлии, ииака шиио најгоолемо влијание за мислењетио за Туриииее Османлии ми е оя макеоонскийе йисайели.

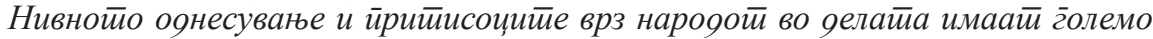
влијание врз моейо размислување яека Туриите биле грубб и алчен нароя.

Моейо мислење е оформено ушие оя многу мала возрасии.

\section{5 Заклучок}

Резултатите од ова истражување се очекува да најдат своја примена во сферата на теоријата, како и во педагошко-образовната практика, каде што наставникот треба да обликува слика компаративно со современиот културно-историскиот контекст. Тоа би подразбирало во наставата да се вклучат и нови книжевни дела од современи турски писатели, кои би граделе кај ученикот однос кон литературата од денешна Турција, во која може да се говори и за Османлиите. Но, сепак, како артефакт, тоа е содржина што покажува поинаква слика за начинот на однесување и на живеење на овој етникум денес, а тоа 
би имало клучно значење, доколку тој современ однос стане практика што во Северна Македонија ќе може да формира граѓани кои во односот кон своите сограѓани Турци гледаат, пред сѐ, луѓе, а не само стереотип на „поробувачот што е насилник“.

\section{Библиографија}

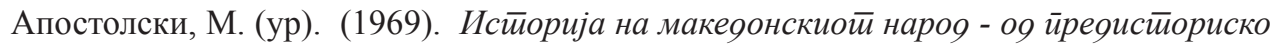
време gо крајой на XVIII век, книга йрва.Скопје: Нова Македонија.

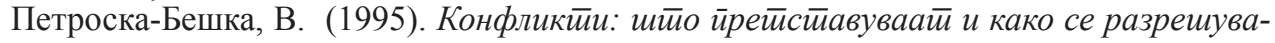
$a \bar{u}$. Скопје: Филозофски факултет.

Ротенберг, В. (1997). Дистиервег̄ за учийелот̄. Скопје: Звезда.

Тодорова, М. (2012). Превеgувањейо за яеца како меѓукулйурна комуникаиија. Скопје: Вермилион.

Штајнбергер, И. и Кузмановиќ, Б. (1985). Психолог̄ија. Скопје: Просветно дело.

Fera, V. e Martelli, M. (1998). Agnolo Poliziano: poeta, scrittore, filologo: atti del Convegno internazionale di studi, Montepulciano 3-6 novembre 1994. Firenze: Le lettere.

Weeks, D. (1994). The Eight Essential Steps to Conflict Resolution: Preseverving Relationships at Work, at Home, and in the Community. London: Tarcher Perigee.

\section{Извори}

Абаџиев, Ѓ. (1961). Пустиина. Скопје: Македоника.

Попов, С. (1966). Крйен живой. Скопје: Наша книга.

Попов, С. (1987). Калеш Анѓa. Скопје: Наша книга.

Чернодрински, В.(1969). Макеоонска крвава сваяба. Скопје: Просвета. 
